\title{
Multielemental Analysis of Gold Ore Samples from Underground Artisanal Gold Mines in Tongo, Upper East Region of Ghana: Implications of Occupational Exposure
}

Doyi $I^{1^{\star}}$, Essumang $D^{2}$, Nyarku $\mathbf{M}^{1}$, Gbeddy $\mathbf{G}^{1}$, Ackah $\mathbf{M}^{3}$, Ameho $\mathrm{E}^{1}$ and Owusu-Bentil $\mathbf{N}^{3}$

${ }^{1}$ National Radioactive Waste Management Centre, Ghana Atomic Energy Commission, PO Box LG 80, Legon-Accra, Ghana

${ }^{2}$ Department of Chemistry, School of Physical Sciences, University of Cape Coast, Ghana

${ }^{3}$ Nuclear Chemistry and Environmental Research Centre, Ghana Atomic Energy Commission, PO Box LG 80, Legon-Accra, Ghana

\begin{abstract}
Background: The presence of gold deposits discovered in rural areas in Ghana has attracted a lot of unemployed youth and smallscale mining ventures to the rural communities. The activities of illegal small-scale gold mining (locally referred to as "galamsey") in the community is causing serious environmental havoc and destruction. The results of heavy element profiling of gold ores associated with the underground artisanal gold mining activities of the Tongo mines in the Upper East Region of Ghana have been reported in this paper. The analysis was made to assess the occupational exposure of the miners as well as to investigate the environmental impact of toxic heavy metals.
\end{abstract}

Results: Gold ores from seven artisanal gold mines were sampled and analysed for heavy elemental content using Atomic Absorption Spectroscopy technique. The ranges of major elements detected were: $\mathrm{Pb}(14.16-37.00 \mathrm{mg} / \mathrm{kg})$; Co $(6.40-31.52 \mathrm{mg} / \mathrm{kg})$; As $(25.08-27.36$ $\mathrm{mg} / \mathrm{kg}) ; \mathrm{Hg}(5.04-6.16 \mathrm{mg} / \mathrm{kg}) ; \mathrm{Ni}(69.44-332.40 \mathrm{mg} / \mathrm{kg}) ; \mathrm{Mn}(259.04-528.64 \mathrm{mg} / \mathrm{kg})$ and Cd were Below Detectable Limits (BDL). The potential health risk assessment calculated for a lifetime of exposure for ingestion, inhalation and dermal contact were determined as the cumulative carcinogenic risk for children and adults. Risk assessment indicated that the carcinogenic risk is completely insignificant but the cumulative non-carcinogenic Hazard Index recorded alarming values of $4.55 \mathrm{E}+00$ to $4.15 \mathrm{E}+01$ and $8.53 \mathrm{E}-01$ to $3.43 \mathrm{E}+01$ for children and adults respectively.

Conclusions: The investigations show that the concentrations of $\mathrm{Pb}$, As and Ni which are known carcinogens presents no significant carcinogenic lifetime risk due to ingestion, inhalation and/or dermal contact but the non-carcinogenic risk, expressed as the Hazardous Index $(\mathrm{HI})$, is not so benevolent; the cumulative index for all elements exceeding 1 and should be of concern, particularly in cases of the exposure of children.

Capsule abstract: The concentrations of elements ranged from $5.04 \mathrm{mg} / \mathrm{kg}$ for $\mathrm{Hg}$ to 528.64 for Mn with highest Hazard Index being $4.55 \mathrm{E}+00$ to $4.15 \mathrm{E}+01$ and $8.53 \mathrm{E}-01$ to $3.43 \mathrm{E}+01$ for children.

Keywords: Artisanal; Atomic absorption spectroscopy; Gold ore; Tongo; Heavy metals

\section{Introduction}

The abundance of Gold in most regions in Ghana has led to widespread small scale artisanal mining, a phenomenon popularly referred to as "galamsey" locally. This phenomenon has its attendant environmental and social problems such as the wanton destruction of water bodies, other forms of environmental pollution, and escalation in crime rates.

One such community where the Galamsey trade is plied is Tongo in the Talensi-Nabdam District of the Upper East Region of Ghana. Preliminary investigation in the community revealed that miners do their work without any form of protective apparel such as gloves, respirators, and helmets. Of more serious concern is the fact that "galamsey" operatives smoke, drink and eat during their work without washing their hands within the vicinity of the mines. Miners are therefore potentially at risk of exposures to harmful elements such as arsenic, radon etc. which may be present in the ores and mines or introduced as result of mineral processing.

By definition, heavy metals are any metallic chemical element that has a relatively high density (superior to $5 \mathrm{~g} / \mathrm{cm}^{3}$ ); most of them are toxic or carcinogenic even at low concentrations, such as mercury $(\mathrm{Hg})$, cadmium $(\mathrm{Cd})$, arsenic (As) and chromium (Cr).

Poisoning by exposure to heavy metals is well known to affect central nervous function, damage blood composition, lungs, kidneys, liver and other vital organs. Long-term exposure can cause slower progressing physical, muscular, and neurological degenerative processes. Allergies may also occur or their compounds may become carcinogenic as a result of repeated long term contact.

Harmful substances in the environment have been shown to have many effects on human health, agriculture productivity and natural ecosystem [1]. It has been known that several metals are toxic to man, animals and plants; however some biochemical reactions within living organisms such as enzyme activities and components of controlled mechanisms (in muscle) have been found to involve several metallic elements. Some are referred to as essential trace elements and thus essential to life, but others are non-essential, detrimental or toxic to life.

Non-essential trace metals or heavy metals for example $\mathrm{Hg}, \mathrm{Cd}$, $\mathrm{Pb}$ and As present detrimental and toxic effect to life under normal background concentration. The detrimental effects of these metals include competition for sites with essential metabolites and the replacements of ion reactions on -SH groups and the damage to cell membranes.

*Corresponding author: Israel Doyi, National Radioactive Waste Management Centre, Ghana Atomic Energy Commission, PO Box LG 80, Legon-Accra, Ghana Tel: +233302401272; Fax: +233302400807; E-mail: i.doyi@gaecgh.org

Received June 15, 2015; Accepted January 27, 2016; Published February 03 , 2016

Citation: Doyi I, Essumang D, Nyarku M, Gbeddy G, Ackah M, et al. (2016) Multielemental Analysis of Gold Ore Samples from Underground Artisanal Gold Mines in Tongo, Upper East Region of Ghana: Implications of Occupational Exposure. J Environ Anal Toxicol 6: 350. doi:10.4172/2161-0525.1000350

Copyright: (c) 2016 Doyi I, et al. This is an open-access article distributed under the terms of the Creative Commons Attribution License, which permits unrestricted use, distribution, and reproduction in any medium, provided the original author and source are credited. 
Citation: Doyi I, Essumang D, Nyarku M, Gbeddy G, Ackah M, et al. (2016) Multielemental Analysis of Gold Ore Samples from Underground Artisanal Gold Mines in Tongo, Upper East Region of Ghana: Implications of Occupational Exposure. J Environ Anal Toxicol 6: 350. doi:10.4172/2161-0525.1000350

The concentrations of major elements have been detected in artisanal gold ore and sediments in Migori, Southwest Kenya as: titanium $(711.41-10,766.67 \mathrm{mg} / \mathrm{kg})$; cobalt $(82.65-1,010.00 \mathrm{mg} / \mathrm{kg})$; zinc $(29.90-63,210 \mathrm{mg} / \mathrm{kg})$; arsenic $(29.30-8,246.59 \mathrm{mg} / \mathrm{kg}) ;$ gold $(14.07-73.48 \mathrm{mg} / \mathrm{kg})$; lead (16.31-14,999.40 $\mathrm{mg} / \mathrm{kg})$ and mercury $(16.10-149.93 \mathrm{mg} / \mathrm{kg})$. The average concentration of the heavy toxic metals i.e., arsenic, lead, titanium and zinc were found to be above 50 $\mathrm{mg} / \mathrm{kg}$ as recommended by World Health Organization [2].

In a comparative study, Asumadu-Sakyi et al. [3] reported higher levels of total $\mathrm{Hg}$ concentrations in surface soil samples at the sites with extensive small scale "galamsey" mining activities than at the non-small-scale "galamsey" mining sites. The findings generally gave evidence of severe mercury pollution in Sikakrom of Kenyasi No. 1 in the Asutsifi District of the Brong Ahafo Region of Ghana due to artisanal mining.

This present study seeks to investigate the heavy metal content from the artisanal gold mines in Tongo with the specific goal to determine their potential health risks as a cumulative carcinogenic and non-carcinogenic risk for children and adults, especially those occupationally at risk. A multi-step procedure comprising data collection (gathering and analysing the site data relevant to human health), exposure assessment (estimation of the magnitude of actual and/or potential human exposures), toxicity assessment (determination of adverse health effects associated with exposure to different chemicals) and risk characterization (summarizes and combines the outputs of the calculations of exposure and toxicity assessments) was adopted. The heavy metals $\mathrm{Pb}, \mathrm{Co}, \mathrm{As}, \mathrm{Hg}, \mathrm{Ni}, \mathrm{Mn}$, and $\mathrm{Co}$ were analysed by atomic absorption spectroscopy and the calculation of potential health risk based on the US Environmental Protection Agency health risk assessment model developed by the USEPA [4] and reported by Gržetić and Ghariani [5] (Figures 1 and 2).

\section{Study area}

Tongo is an artisanal mining community in the Talensi-Nabdam district of the Upper East Region. Mining settlements were named after large towns, mining communities in southern Ghana or rich institutions. Awumbila et al. [6] have reported that settlements were given names such as Accra (the national capital), "Kejetia", "Bantama" (large commercial centres in Kumasi, Ashanti Region), "Obuasi", "Tarkwa" (well-known large gold mining towns in Southern Ghana), "Gold Coast" (former name of Ghana), "World Bank" and "Croatia". "Kejetia" is the oldest community in this cluster. It was so crowded when mining started that it looked like Kejetia market, the largest market in Kumasi in the Ashanti Region and hence its name. Names of settlements appeared to convey the size and population of the new mining area when it opened. Each name also tried to outdo the one before it. There was rivalry among settlements as to which started first, which was larger in population size and which had the richest ore deposits. In-depth interviews revealed that although initially mining started in "Croatia" around 1995 for a brief period, "Kejetia" was the oldest settlement in terms of historical age and size of population $[7,8]$.

\section{Materials and Methods}

Gold ore samples were collected from 7 different mines for analysis. The sampled mines were selected based on occupancy factors, geological considerations, accessibility and previous safety records. Rock samples were wrapped in non coloured polyethylene bags and transported to the A. Chatt Chemical Laboratory of Ghana Atomic Energy Commission, Accra. The ore samples were crashed, milled using
Laboratory Mortar Grinder (Pulverisette-2), homogenized. Samples were sieved through a $100 \mu \mathrm{m}$ mesh and stored in labelled non coloured polyethylene bags ready for further analysis. The powdered samples were digested by adding $5 \mathrm{ml}\left(65 \% \mathrm{HNO}_{3}\right), 2 \mathrm{ml}(\mathrm{HF})$ and $2 \mathrm{ml}(35 \%$ $\mathrm{HCl})$ to $0.25 \mathrm{~g}$ of the powdered samples in a Teflon beaker and digested per the digestion code 266 (Milestone acid digestion cookbook 1996) in ETHOS 900 microwave digester. Once the digestion was complete, the samples were allowed to cool, and then transferred into clean $25 \mathrm{ml}$ volumetric flask and diluted to $20 \mathrm{ml}$ with deionized water. Lead $(\mathrm{Pb})$, cobalt $(\mathrm{Co})$, arsenic (As), mercury (Hg), nickel $(\mathrm{Ni})$, manganese $(\mathrm{Mn})$ and cadmium $(\mathrm{Cd})$ in the digested samples were determined using AA240 FS atomic absorption spectrometer as per Table 1. Acetylene gas and air were used as fuel and oxidant, respectively. The flow rates for acetylene and air, 2 and $13.5 \mathrm{~L} / \mathrm{min}$, respectively, were kept constant for the analysis of the metals. The analysis of $\mathrm{Mg}$ by atomic absorption spectrometer was achieved by adding $9 \mathrm{ml}$ of lanthanum solution to 1 $\mathrm{ml}$ of sample prior to analysis $[9,10]$.

\section{Quality assurance}

Strict QA/QC measures were adopted to ensure reliability of the results. All chemicals and reagents used were of high purity. Glassware used was cleaned thoroughly with detergent and rinsed several times using deionized water. Deionized water was used for all dilution purposes. For the purposes of detection and quantification limits of the AAS, a blank solution was read 25 times, and the standard deviations were calculated for the noise levels generated for each of the elements of interest. The detection limit (LOD) for each element was achieved as follows:

$$
L O D=\frac{3 \times S}{m}
$$

Where $\mathrm{S}$ is the standard deviation of the blank readings and $\mathrm{m}$ represents the gradient of the calibration curve for each element. The limit of quantification was calculated using $10 \mathrm{~s} / \mathrm{m}$. The accuracy and reproducibility of the analytical procedure was determined by spiking and homogenizing three replicates of each of three samples selected at random. Triplicate of each sample was spiked with three different concentrations of the element of interest as follows: $\mathrm{Pb}$ (2.0, 5.0 and 10.0 $\mathrm{mg} / \mathrm{l})$, Co $(2.0,5.0$ and $8.0 \mathrm{mg} / \mathrm{l})$, As $(0.02,0.04,0.06), \mathrm{Hg}(0.02,0.04$ $0.06), \mathrm{Ni}(2.0,5.0$ and $10.0 \mathrm{mg} / \mathrm{l}), \mathrm{Mn}(1.0,2.0,5.0)$, and $\mathrm{Cd}(0.5,2.0$ and $3.0 \mathrm{mg} / \mathrm{l}$ ) and treated in a similar manner as the samples [11]. The recoveries obtained for each of the elements are shown in Table 2. The absorbances measured by the AAS were converted to concentrations using standard calibration curves. One thousand milligrams per liter single element standards of the elements of interest, obtained from Fluka Analytical (Sigma Aldrich Chemie GmbH, Switzerland), were diluted using $10 \% \mathrm{HNO}_{3}$ and used to generate the calibration curves for the AAS analysis. The regression data of the calibration curves for AAS is shown on Table 3.

Plain data on the metal content of soil is sometimes insufficient to describe the full risk that arises from the exposure of humans, both children and adults, to different heavy metals from rocks/soil, particularly in the case when more details on human health risk are required (Table 4 ).

Exposure of humans to rocks/soil actually is through dust exposure that comprises (i) inhalation exposure and/or (ii) oral exposure (ingestion). For such exposition, EPA guidance recommends daily rates of $20 \mathrm{mg} / \mathrm{h}$ for children and $10 \mathrm{mg} / \mathrm{h}$ for adults $[7,8]$. For the purposes of this study, risk characterization comprises calculations of 
Citation: Doyi I, Essumang D, Nyarku M, Gbeddy G, Ackah M, et al. (2016) Multielemental Analysis of Gold Ore Samples from Underground Artisanal Gold Mines in Tongo, Upper East Region of Ghana: Implications of Occupational Exposure. J Environ Anal Toxicol 6: 350. doi:10.4172/2161-0525.1000350

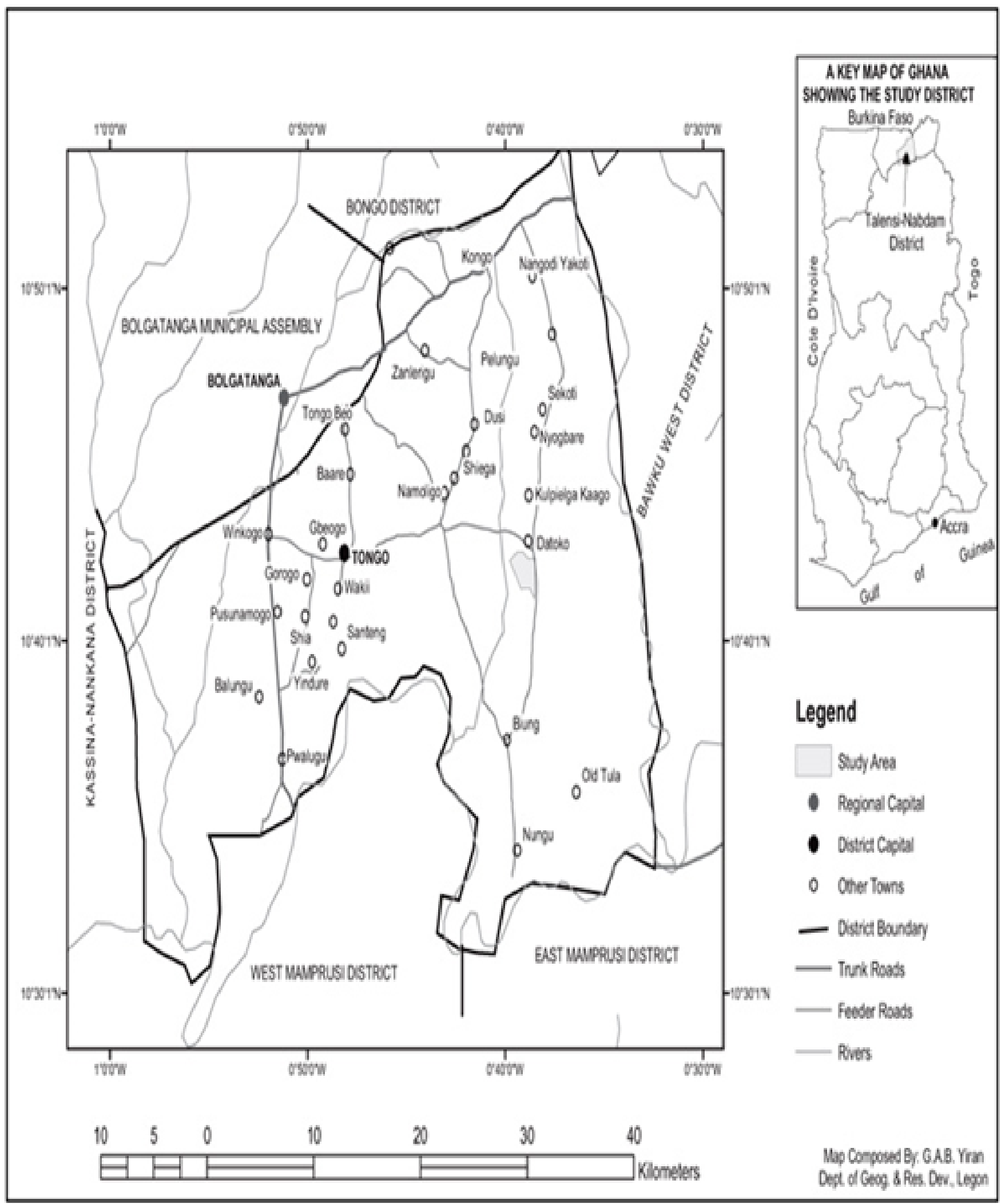

Figure 1: Map of Talensi-Nabdam District showing the study area [6]. 


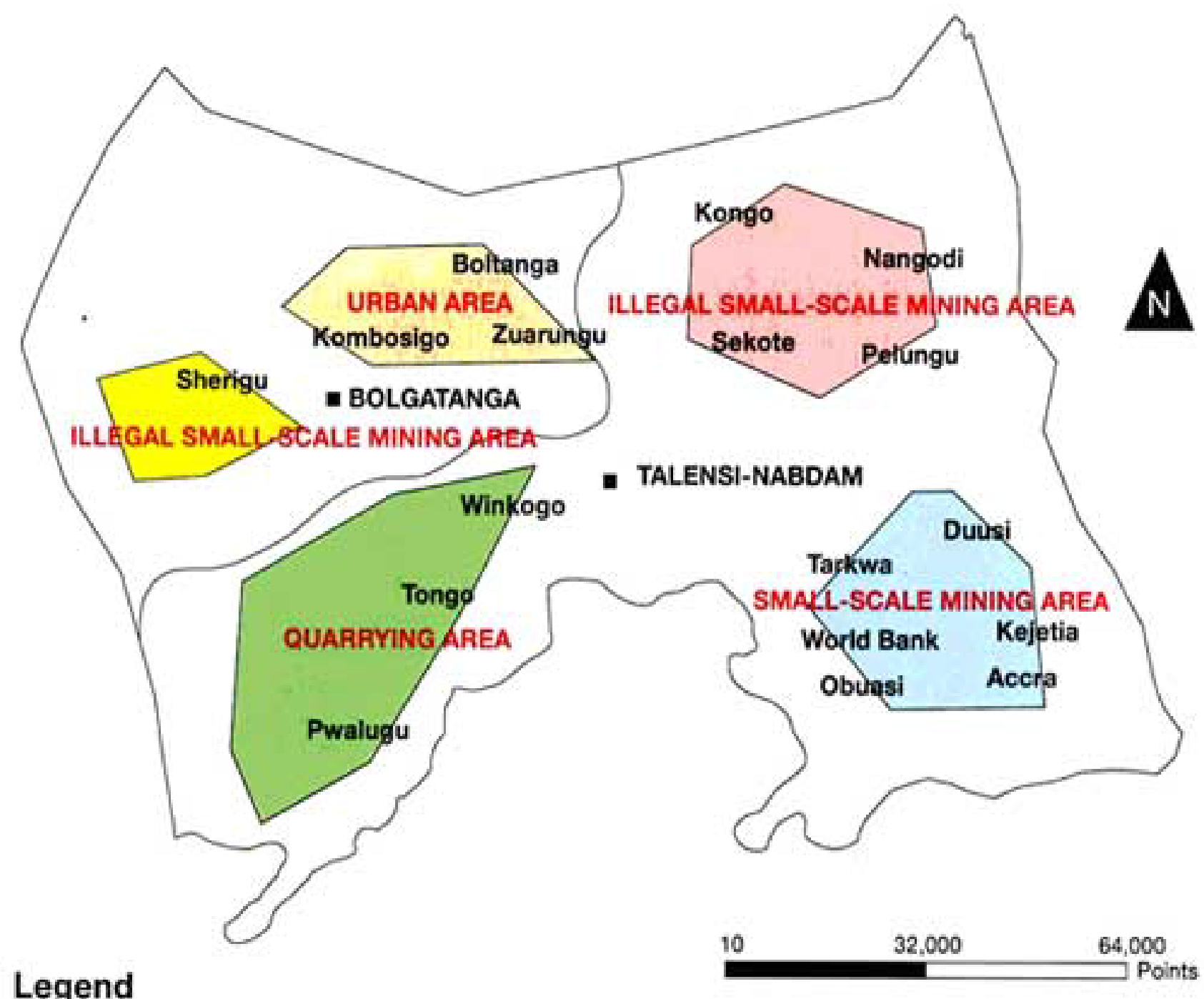

\section{Legend}

Bolgatanga and Talensi-Nabdam

\section{Land-cover types}

Grasses, built-up/barren land

Grasses, bulit-up/barren land

Grasses, built-up/barren land

Fow grasses, dominant barren land

Few woodland, grasses and barren land

Figure 2: Map showing mining settlements [14]. 
Citation: Doyi I, Essumang D, Nyarku M, Gbeddy G, Ackah M, et al. (2016) Multielemental Analysis of Gold Ore Samples from Underground Artisanal Gold Mines in Tongo, Upper East Region of Ghana: Implications of Occupational Exposure. J Environ Anal Toxicol 6: 350. doi:10.4172/2161-0525.1000350

Page 5 of 8

\begin{tabular}{|c|c|c|c|c|c|c|c|}
\hline Parameter & $\mathrm{Pb}$ & Co & As & $\mathrm{Hg}$ & $\mathrm{Ni}$ & Mn & Cd \\
\hline Wavelength, nm & 224.8 & 240.7 & 193.7 & 253.7 & 232 & 279.5 & 228.8 \\
\hline Slit width, nm & 0.2 & 0.2 & 0.5 & 0.2 & 0.2 & 0.2 & 0.5 \\
\hline Lamp current, $\mathrm{mA}$ & 5.0 & 7.0 & 10.0 & 4.0 & 4.0 & 5.0 & 4.0 \\
\hline $\begin{array}{l}\text { Background } \\
\text { correction }\end{array}$ & ON & OFF & OFF & OFF & ON & OFF & OFF \\
\hline Precision, \% & $0.6-1.0$ & $0.3-1.0$ & $0.02-0.08$ & $0.02-0.9$ & $0.5-1.3$ & $0.02-1.0$ & $0.2-0.9$ \\
\hline Fuel & Acetylene & Acetylene & Acetylene & Acetylene & Acetylene & Acetylene & Acetylene \\
\hline Support & Nitrous oxide & Nitrous oxide & Nitrous oxide & Nitrous oxide & Nitrous oxide & Nitrous oxide & Nitrous oxide \\
\hline
\end{tabular}

Table 1: Operating parameters of the AAS (Varian AA240FS Atomic Absorption Spectrometer).

\begin{tabular}{|c|c|c|c|c|}
\hline Metal & Spike & Recovery & $\%$ Recovery & $\%$ Deviation \\
\hline $\mathrm{Pb}$ & $\begin{array}{l}2.00 \\
5.00 \\
10.0\end{array}$ & $\begin{array}{l}2.06 \\
5.10 \\
9.86\end{array}$ & $\begin{array}{c}103 \\
102 \\
98.60\end{array}$ & $\begin{array}{l}3.0 \\
2.0 \\
1.4\end{array}$ \\
\hline Co & $\begin{array}{l}2.00 \\
5.00 \\
8.00\end{array}$ & $\begin{array}{l}1.98 \\
4.96 \\
7.79\end{array}$ & $\begin{array}{l}99.0 \\
99.2 \\
97.4\end{array}$ & $\begin{array}{l}1.0 \\
0.8 \\
2.6\end{array}$ \\
\hline As & $\begin{array}{l}0.02 \\
0.04 \\
0.06\end{array}$ & $\begin{array}{l}0.018 \\
0.036 \\
0.061\end{array}$ & $\begin{array}{c}90 \\
90 \\
101.7\end{array}$ & $\begin{array}{c}10.0 \\
10.0 \\
8.3\end{array}$ \\
\hline $\mathrm{Hg}$ & $\begin{array}{l}0.02 \\
0.04 \\
0.06\end{array}$ & $\begin{array}{l}0.021 \\
0.042 \\
0.062\end{array}$ & $\begin{array}{c}105 \\
105 \\
103.3\end{array}$ & $\begin{array}{l}5.0 \\
5.0 \\
3.3\end{array}$ \\
\hline $\mathrm{Ni}$ & $\begin{array}{l}2.00 \\
5.00 \\
10.0\end{array}$ & $\begin{array}{l}2.03 \\
4.89 \\
9.97\end{array}$ & $\begin{array}{l}101.5 \\
97.80 \\
99.70\end{array}$ & $\begin{array}{l}1.5 \\
2.2 \\
0.3\end{array}$ \\
\hline Mn & $\begin{array}{l}1.00 \\
2.00 \\
5.00\end{array}$ & $\begin{array}{l}1.003 \\
1.993 \\
5.00\end{array}$ & $\begin{array}{l}100.3 \\
99.70 \\
100.0\end{array}$ & $\begin{array}{l}0.3 \\
0.3 \\
0.0\end{array}$ \\
\hline Cd & $\begin{array}{l}0.50 \\
2.00 \\
3.00\end{array}$ & $\begin{array}{l}0.48 \\
2.01 \\
2.96\end{array}$ & $\begin{array}{c}96 \\
100.5 \\
98.67\end{array}$ & $\begin{array}{c}4 \\
0.5 \\
1.33\end{array}$ \\
\hline
\end{tabular}

Table 2: Recoveries of spiked samples.

\begin{tabular}{|c|c|c|c|}
\hline Parameter & Technique & Equation \\
\hline $\mathrm{Pb}$ & AAS & $\mathrm{y}=0.0379 \mathrm{X}+0.0007$ \\
\hline $\mathrm{Co}$ & AAS & $\mathrm{y}=0.0818 \mathrm{X}+0.0091$ \\
\hline $\mathrm{As}$ & AAS & \\
\hline $\mathrm{Ni}$ & AAS & $\mathrm{y}=0.0945 \mathrm{X}-0.0179$ \\
\hline $\mathrm{Mn}$ & AAS & 0.99961 \\
\hline $\mathrm{Cd}$ & AAS & $\mathrm{y}=0.205 \mathrm{X}+0.0152$ \\
\hline
\end{tabular}

Table 3: Regression data of calibration curve.

\begin{tabular}{|c|c|c|c|c|c|c|c|c|c|c|c|}
\hline \multirow{2}{*}{$\begin{array}{l}\text { Element } \\
(\mathrm{mg} / \mathrm{kg})\end{array}$} & \multicolumn{7}{|c|}{ Mine } & \multirow{2}{*}{$\begin{array}{c}\text { Minimum } \\
\text { Concentration }\end{array}$} & \multirow{2}{*}{$\begin{array}{c}\text { Maximum } \\
\text { Concentration }\end{array}$} & \multirow[t]{2}{*}{ Mean } & \multirow[t]{2}{*}{ Standard Deviation } \\
\hline & 1 & 2 & 3 & 4 & 5 & 6 & 7 & & & & \\
\hline Lead & 14.16 & 15.04 & 15.60 & 16.16 & 21.84 & 17.76 & 37.68 & 14.16 & 21.84 & 19.75 & 7.68 \\
\hline Cobalt & 6.40 & 19.12 & 12.72 & 18.08 & 12.80 & 31.52 & 14.88 & 6.40 & 19.12 & 16.50 & 7.29 \\
\hline Arsenic & 25.20 & 25.36 & 26.08 & 25.76 & 26.40 & 26.24 & 27.36 & 25.20 & 27.36 & 26.06 & 0.67 \\
\hline Mercury & 5.28 & 5.04 & 5.44 & 5.28 & 5.76 & 6.00 & 6.16 & 5.04 & 6.16 & 5.57 & 0.15 \\
\hline Nickel & 219.20 & 121.52 & 69.44 & 100.16 & 103.20 & 196.32 & 332.40 & 69.44 & 332.40 & 163.18 & 85.33 \\
\hline Manganese & 283.28 & 269.68 & 405.18 & 377.19 & 350.56 & 528.64 & 259.04 & 259.04 & 528.64 & 353.37 & 88.47 \\
\hline Cadmium & $\mathrm{BDL}$ & BDL & $\mathrm{BDL}$ & BDL & $\mathrm{BDL}$ & $\mathrm{BDL}$ & $\mathrm{BDL}$ & BDL & BDL & BDL & BDL \\
\hline
\end{tabular}

Table 4: Heavy metals concentration in ore samples (BDL=Below Detection Limit). 
Citation: Doyi I, Essumang D, Nyarku M, Gbeddy G, Ackah M, et al. (2016) Multielemental Analysis of Gold Ore Samples from Underground Artisanal Gold Mines in Tongo, Upper East Region of Ghana: Implications of Occupational Exposure. J Environ Anal Toxicol 6: 350. doi:10.4172/2161-0525.1000350

Page 6 of 8

carcinogenic and non-carcinogenic risk for ingestion, inhalation and dermal contact [12-15]

Basic formulas used for the calculation of dose received through the different pathways are presented as

$$
\begin{aligned}
& \mathrm{CDI}_{\text {ingestion }}=\mathrm{C} \times \frac{\operatorname{IngR\times EF\times ED}}{B W \times A T} \times 10^{-6} \\
& \mathrm{CDI}_{\text {inhalation }}=\mathrm{C} \times \frac{\operatorname{InhR\times EF\times ED}}{P E F \times B W \times A T} \\
& \mathrm{CDI}=\mathrm{C} \times \frac{\mathrm{SA} \times \mathrm{SL} \times \mathrm{ABS} \times \mathrm{EF} \times \mathrm{ED}}{\mathrm{BW} \times \mathrm{AT}} \times 10 \\
& \mathrm{HQ}=\frac{\mathrm{CDI}}{\mathrm{R} \mathrm{D}} \\
& \mathrm{HI}=\sum \mathrm{HQ}=\mathrm{HQ}_{\text {ing }}+\mathrm{HQ}_{\text {inh }}+\mathrm{HQ}_{\text {dem }}
\end{aligned}
$$

As carcinogenic substances, $\mathrm{Pb}$, As and $\mathrm{Ni}$ were selected to assess the carcinogenic hazard risk (Total Risk) using equations

$$
\mathrm{CDI}_{\text {ing-ca }}=\frac{\mathrm{C} \times \mathrm{IR} \times \mathrm{EF}}{\mathrm{AT}_{\text {ca }}} \times 10^{-6}
$$

Where

$$
\begin{aligned}
& \operatorname{IR}=\frac{E D_{\text {child }} \times \operatorname{Ing} R_{\text {child }}}{B W_{\text {child }}}+\frac{\left(E D_{\text {adult }}-E D_{\text {child }}\right) \times \operatorname{Ing} R_{\text {adult }}}{B W_{\text {adult }}} \\
& \mathrm{CDI}_{\text {inh-ca }}=\frac{C \times E F \times E T \times E D}{P E F \times 24 \times A T_{c a}} \times 10^{3} \\
& \mathrm{CDI}_{\mathrm{derm}-\mathrm{ca}}=\frac{C \times A B S_{d} \times E F \times D F S_{a d j}}{A T_{c a}} \times 10^{-6} \\
& \text { Risk }=C D I_{c a} \times C S F \\
& \text { Total Risk }=\text { Risk }_{\text {ing }}+\text { Risk }_{\text {inh }}+\text { Risk }_{\text {dermal }} \\
& =C D I_{\text {ing-ca }} \times C S F+C D I_{i n h-c a} \times I U R+\frac{C D I_{\text {dermal }-c a} \times C S F_{i n g}}{A B S_{G I}}
\end{aligned}
$$

Where $C D I_{\text {ing }}, C D I_{\text {inh }}, C D I_{\text {dermal }}$ are the chronic daily intake or dose contacted through oral ingestion $\left(\mathrm{mg} \mathrm{kg}^{-1} \mathrm{~d}^{-1}\right)$, inhalation $(\mathrm{mgm}$ ${ }^{3}$ for non-cancer and $\mu \mathrm{gm}^{-3}$ for cancer) and dermal contact with soil particles $\left(\mathrm{mg} \mathrm{kg}^{-1} \mathrm{~d}^{-1}\right)$, respectively. $R f D$ was the reference dose, and $R f D_{\text {ing }}$ (chronic oral reference dose), $R f C_{i n h}$ (chronic inhalation reference concentration), $R d D_{\text {dermal }}$ (chronic dermal reference dose) via three exposure routes. CSF was the chronic slope factor. The definitions and values of other parameters used for the calculation of ingestion, inhalation and dermal of soil are presented in Table 5 [16].
The main descriptive statistics of the analytical results are presented in Table 4. The sources of all these elements are anthropogenic as the gold ores were extracted directly from underground mines. The concentrations of $\mathrm{Pb}, \mathrm{Co}$, As, and $\mathrm{Hg}$ were quite low but the concentrations of $\mathrm{Ni}$ and $\mathrm{Mn}$ were comparable to the levels found in soil from the central zone of Belgrade [5]. Despite its low concentrations, As appeared as the single largest contributor to the overall risk after Ni. This is critical as As is a known carcinogen capable of causing increased lung cancer mortality through inhalation and dermal contact and several internal organ cancers through ingestion [9] (Table 6). The investigations show that the concentrations of $\mathrm{Pb}, \mathrm{As}$ and $\mathrm{Ni}$ which are known carcinogens presents no significant carcinogenic lifetime risk due to ingestion, inhalation and/or dermal contact with soil. No matter how small the probability is, a carcinogenic risk exists and varies from the maximum value of $1.60 \mathrm{E}-02$ in case of $\mathrm{Ni}$ to the minimum value of $1.99 \mathrm{E}-05$ for $\mathrm{Pb}$ (Table 7). On the other hand, the non-carcinogenic risk, expressed as the Hazardous Index (HI), is not so benevolent; the cumulative index for all elements exceeds 1 . As a rule, the greater the value of CDI/RfD above unity, the greater is the level of concern, particularly in cases of the exposure of children (Table 7). Generally speaking, the hazardous index (HI) for the ingestion of samples is greater in comparison to the corresponding results obtained for adults [17]. This is an alarming value for toxicologists since it indicates that the health of children is endangered, but what kind of health effects could evolve from cumulative effects of heavy metals in samples and their influence on children was not the in the scope of this investigation (Figure 3).

There may therefore be the need to control exposure to certain critical groups especially children, and women who work on contract basis in some processing areas. Of particular interest are young children who accompany their parents to work. Others include visitors and members of the general public because the mines and processing areas are not far separated from the residential environment in all the mining communities. Although both children and adults may be exposed to the same pathways, children's rates of exposure to compounds (as expressed per unit body weight) are frequently higher and they may be subject to different types of health risks. Generally children younger than the age of 6 are considered critical receptors as they may easily get exposed by the ingestion of contaminated samples. Infants and children are critical receptors either due to their critical stages of physical and mental development or due to the fact that they receive higher pollutant dose compared to adults as they have lower body weight and higher breathing rate. Also, children's developing organs and tissues are more vulnerable to the toxic effects of certain chemicals. In general, children living in the vicinity of source emissions have the highest health risks [10].

\section{Conclusion}

This study provides some early warning signals about heavy metal pollution from artisanal gold mining for EIA practice. Understanding the type, degree, scale and sources of heavy metal contaminations are essential for environmental management to reduce pollutant emission and minimize the hazard risks to human health. Furthermore, the results will help to design effective methods for successful land restoration. It is suggested that complete exposure assessment and a consequent risk assessment not only the direct emissions to the atmosphere but also the impacts of heavy metals deposition, transport and transfer in the food chain and in the drinking water and their risk analysis be considered in order to reduce or to mitigate exposure to heavy metals. 
Citation: Doyi I, Essumang D, Nyarku M, Gbeddy G, Ackah M, et al. (2016) Multielemental Analysis of Gold Ore Samples from Underground Artisanal Gold Mines in Tongo, Upper East Region of Ghana: Implications of Occupational Exposure. J Environ Anal Toxicol 6: 350. doi:10.4172/2161-0525.1000350

Page 7 of 8

\begin{tabular}{|c|c|c|c|c|}
\hline \multirow[t]{2}{*}{ Parameters } & \multirow[t]{2}{*}{ Unit } & \multirow[t]{2}{*}{ Definition } & \multicolumn{2}{|c|}{ Value } \\
\hline & & & Child & Adult \\
\hline $\mathrm{C}$ & $\mathrm{mg} / \mathrm{kg}$ & heavy metal concentration & & \\
\hline $\mathrm{ABS}_{\mathrm{d}}$ & -- & dermal absorption factor & 0.03 & 0.001 \\
\hline AF & $\mathrm{mg} / \mathrm{cm}^{2}$ & soil to skin adherence factor & 0.2 & 0.07 \\
\hline BW & $\mathrm{kg}$ & body weight & 16.2 & 61.8 \\
\hline ED & year & exposure duration & 6 & 30 \\
\hline EF & $d /$ year & exposure frequency & 350 & 350 \\
\hline ET & $\mathrm{h} / \mathrm{d}$ & exposure time & 24 & 24 \\
\hline IngR & $\mathrm{mg} / \mathrm{d}$ & soil ingestion rate & 200 & 100 \\
\hline SA & $\mathrm{cm}^{2}$ & skin surface area available for exposure & 2800 & 5700 \\
\hline$A T_{n c}$ & d & averaging time for non-carcinogenic & \multicolumn{2}{|c|}{$\mathrm{ED} \times 365$} \\
\hline AT & d & averaging time for carcinogenic & \multicolumn{2}{|c|}{$\mathrm{LT} \times 365$} \\
\hline DFS $_{\text {adj }}$ & $\mathrm{mg} \times$ year $/ \mathrm{kg} / \mathrm{d}$ & soil dermal contact factor-age-adjusted & \multicolumn{2}{|c|}{362.4} \\
\hline IR & $\mathrm{mg} \times$ year $/ \mathrm{kg} / \mathrm{d}$ & soil ingestion rate age-adjusted & \multicolumn{2}{|c|}{113} \\
\hline LT & year & lifetime & \multicolumn{2}{|c|}{72} \\
\hline PEF & $\mathrm{m}^{3} / \mathrm{kg}$ & Soil-to-air particulate emission factor & \multicolumn{2}{|c|}{$1.36 \times 10^{9}$} \\
\hline
\end{tabular}

Table 5: Values of variables for human health risk assessment.

\begin{tabular}{|c|c|c|c|c|c|c|c|c|c|c|c|}
\hline Element & $\operatorname{RfD}_{\text {ing }}$ & $\operatorname{RfD}_{\text {inh }}$ & $\mathbf{R f D}_{\text {dermal }}$ & $H Q_{\text {ing }}$ & $H Q_{\text {inh }}$ & $H Q_{\text {dermal }}$ & $H I=\sum H Q$ & Risk $_{\text {(ing) }}$ & Risk $_{(\text {inh) }}$ & Risk $_{\text {(dermal) }}$ & Total Risk \\
\hline & $\mathrm{CSF}_{\text {ing }}$ & $\mathrm{CSF}_{\mathrm{inh}}$ & $\mathbf{C S F}_{\text {dermal }}$ & & & & & & & & \\
\hline Pb-non cancer & $3.50 \mathrm{E}-03$ & & $5.25 \mathrm{E}-04$ & 8.70E-02 & & $5.83 \mathrm{E}+00$ & $5.92 \mathrm{E}+00$ & & & & \\
\hline $\mathrm{Pb}$-cancer & 8.5E-03 & & & & & & & 2.60E-05 & & & 2.60E-05 \\
\hline Co & $3.00 \mathrm{E}-4$ & & & 8.53E-01 & & & 8.53E-01 & & & & \\
\hline As-non cancer & $3.00 \mathrm{E}-4$ & & $1.23 \mathrm{E}-04$ & $1.35 \mathrm{E}+00$ & & $3.29 \mathrm{E}+01$ & $3.43 E+01$ & & & & \\
\hline As-cancer & $1.50 \mathrm{E}+00$ & $1.51 \mathrm{E}+01$ & $3.66 \mathrm{E}+00$ & & & & & $6.06 \mathrm{E}-03$ & 6.10E-02 & $1.48 \mathrm{E}-02$ & 8.19E-02 \\
\hline $\mathrm{Hg}$ & $3.00 \mathrm{E}-4$ & 8.57E-05 & $2.10 \mathrm{E}-05$ & $2.87 \mathrm{E}-01$ & $1.00 \mathrm{E}+00$ & $4.10 \mathrm{E}+00$ & $5.39 \mathrm{E}+00$ & & & & \\
\hline Ni-non cancer & $2.00 \mathrm{E}-02$ & & $5.40 \mathrm{E}-03$ & $1.27 \mathrm{E}-01$ & & $5.40 \mathrm{E}-03$ & $1.32 \mathrm{E}-01$ & & & & \\
\hline Ni-cancer & & $8.40 \mathrm{E}-01$ & & & & & & & $3.62 \mathrm{E}-08$ & & $3.62 \mathrm{E}-08$ \\
\hline Mn & $4.60 \mathrm{E}-02$ & 1.43E-05 & $1.84 \mathrm{E}-03$ & $1.19 \mathrm{E}-01$ & 1.19E-01 & $3.05 E+00$ & $3.29 \mathrm{E}+00$ & & & & \\
\hline
\end{tabular}

Table 6: Non-carcinogenic hazard index and carcinogenic lifetime risk for individual elements and cumulative risk for different exposure pathways for individual elements as determined for adults.

\begin{tabular}{|c|c|c|c|c|c|c|c|c|c|c|c|}
\hline Element & $R_{f D}$ ing & $R_{f D} D_{\text {inh }}$ & $\mathbf{R f D}_{\text {dermal }}$ & $H Q_{\text {ing }}$ & $H Q_{i n h}$ & $H Q_{\text {dermal }}$ & $H I=\sum H Q$ & Risk $_{\text {(ing) }}$ & $\mathbf{R i s k}_{\text {(inh) }}$ & $\mathbf{R i s k}_{\text {(dermal) }}$ & Total Risk \\
\hline & $\mathrm{CSF}_{\text {ing }}$ & $\operatorname{CSF}_{\mathrm{inh}}$ & $\mathbf{C S F}_{\text {dermal }}$ & & & & & & & & \\
\hline $\begin{array}{c}\text { Pb-non cancer } \\
\text { Pb-cancer }\end{array}$ & $\begin{array}{c}3.50 \mathrm{E}-03 \\
8.5 \mathrm{E}-03\end{array}$ & & $5.25 \mathrm{E}-04$ & 6.68E-01 & & $4.45 \mathrm{E}+00$ & $5.12 \mathrm{E}+00$ & 1.99E-05 & & & 1.99E-05 \\
\hline Co & $3.00 \mathrm{E}-04$ & & & $6.51 \mathrm{E}+00$ & & & $6.51 \mathrm{E}+00$ & & & & \\
\hline $\begin{array}{c}\text { As-non cancer } \\
\text { As-cancer }\end{array}$ & $\begin{array}{l}3.00 \mathrm{E}-04 \\
1.50 \mathrm{E}+00\end{array}$ & $1.51 \mathrm{E}+01$ & $\begin{array}{l}1.23 \mathrm{E}-04 \\
3.66 \mathrm{E}+00\end{array}$ & $1.03 E+01$ & & $2.51 \mathrm{E}+01$ & $3.54 \mathrm{E}+01$ & $4.62 \mathrm{E}-03$ & 4.60E-02 & 1.13E-02 & 6.19E-02 \\
\hline $\mathrm{Hg}$ & $3.00 \mathrm{E}-04$ & 8.57E-05 & $2.10 \mathrm{E}-05$ & $2.32 \mathrm{E}+00$ & $7.75 E+00$ & $3.14 \mathrm{E}+01$ & 4.15E+01 & & & & \\
\hline $\begin{array}{l}\text { Ni-non cancer } \\
\text { Ni-cancer }\end{array}$ & $2.00 \mathrm{E}-02$ & $8.40 \mathrm{E}-01$ & $5.40 \mathrm{E}-03$ & $9.66 \mathrm{E}-01$ & & $3.58 \mathrm{E}+00$ & $4.55 E+00$ & & 1.60E-02 & & 1.60E-02 \\
\hline Mn & 4.60E-02 & 1.43E-05 & $1.84 \mathrm{E}-03$ & $9.10 \mathrm{E}-01$ & 2.93E-01 & $2.324 \mathrm{E}+01$ & $2.44 \mathrm{E}+01$ & & & & \\
\hline
\end{tabular}

Table 7: Non-carcinogenic hazard index and carcinogenic lifetime risk for individual elements and cumulative risk for different exposure pathways for individual elements as determined for children. 
Citation: Doyi I, Essumang D, Nyarku M, Gbeddy G, Ackah M, et al. (2016) Multielemental Analysis of Gold Ore Samples from Underground Artisanal Gold Mines in Tongo, Upper East Region of Ghana: Implications of Occupational Exposure. J Environ Anal Toxicol 6: 350. doi:10.4172/2161-0525.1000350

Page 8 of 8
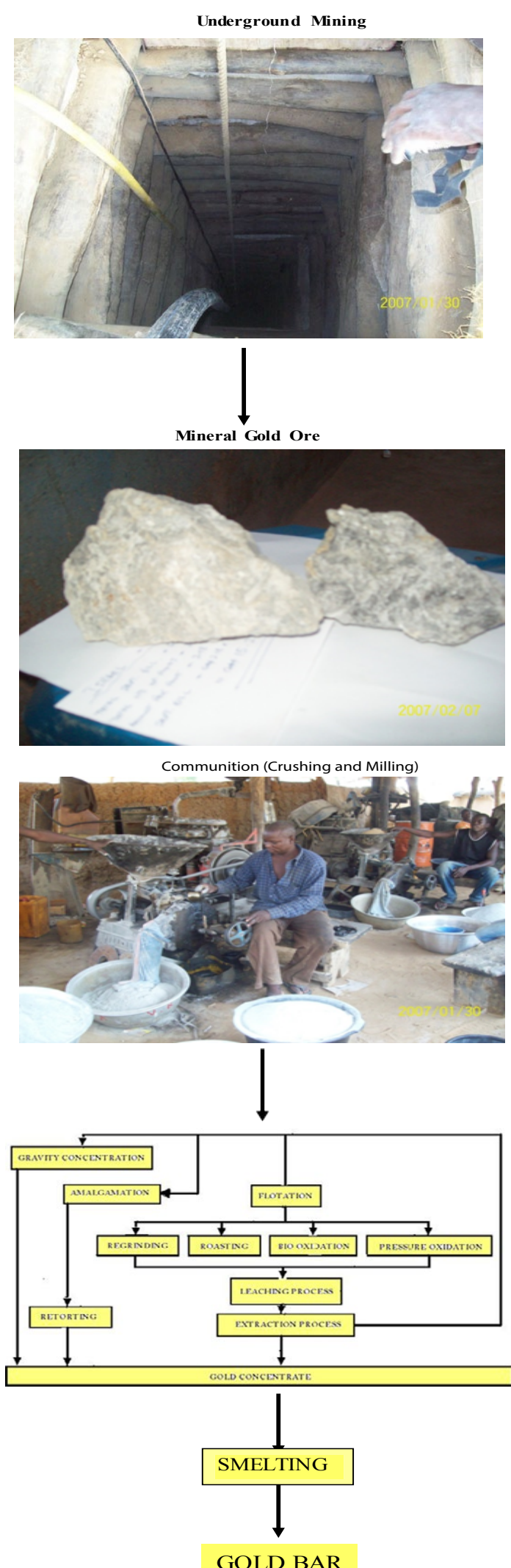

Figure 3: Processing Flow Chart of Gold in Tongo.

\section{Competing Interest}

The authors declare that they have no competing interests

\section{Author's Contributions}

ID part of the group that did sampling also wrote the manuscript. DE supervised sample preparation and analysis to ensure compliance with SOP edited manuscript. MN involved in sampling and writing manuscript. GB part of the team that did the sampling, prepared samples. MA, EA and NO were the scientists that did the actual analysis of samples.

\section{References}

1. Alloway BJ, Ayres DC (1993) Chemical Principles of Environmental Pollution Blackie Academic and Professional, London, UK.

2. Odumo OB, Mustapha AO, Patel JP, Angeyo HK (2011) Multielemental analysis of Migori (Southwest, Kenya) artisanal gold mine ores and sediments by EDX-ray fluorescence technique: implications of occupational exposure and environmental impact. Bull Environ Contam Toxicol 86: 484-489.

3. Asumadu-Sakyi GS, Serfor-Armah Y, Golow AA, Adotey D, Akortia E, et al. (2012) Comparative study of mercury $(\mathrm{Hg})$ in surface soil in gold and non-gold mining towns in Ghana. Elixir Pollution 43: 6550-6555

4. United States Environmental Protection Agency (1989) Risk Assessment Guidance for Superfund Volume 1 Human Health Evaluation Manual (Part A) US Environmental Protection Agency EPA/540/1-89/002.

5. Gržetić I, Ahmed Ghariani RH (2008) Potential health risk assessment for soil heavy metal contamination in the central zone of Belgrade (Serbia). J Serb Chem Soc 73: 923-934.

6. Awumbila M, Tsikata D (2006) Small-scale gold mining and mangrove exploitation in Ghana: Economic liberalisation, changing resource tenures and gendered livelihoods. The International Research Centre, Science for Humanity Bulletin. Chapter 3. Document 5 of 10

7. United States Environmental Protection Agency (1997) Exposure Factors Handbook (1997 Final Report). EPA/600/P-95/002Fa.

8. De Miguel E, Iribarren I, Chacón E, Ordoñez A, Charlesworth S (2007) Riskbased evaluation of the exposure of children to trace elements in playgrounds in Madrid (Spain). Chemosphere 66: 505-513.

9. US Environmental Protection Agency (2005) Integrated Risk Information System (IRIS)

10. Agency for Toxic Substances and Disease Registry (2007) Toxicological Profile for Lead. US Department of Health and Human Services.

11. Agency for Toxic Substances and Disease Registry (1999) Toxicological Profile for Mercury. US Department of Health and Human Services.

12. Agency for Toxic Substances and Disease Registry (2012) Toxicological Profile for Cadmium. US Department of Health and Human Services.

13. Agyemang I (2008) Participatory spatial data analysis to assess environmental degradation. The Geospatial Resource Portal.

14. US Department of Energy (2005) Risk Assessment Information System.

15. US Environmental Protection Agency (2001) Supplemental Guidance for Developing Soil Screening Levels for Superfund Sites. OSWER 9355.4-24. Office of Solid Waste and Emergency Response. US Environmental Protection Agency, Washington DC, USA.

16. United States Environmental Protection Agency (1996) Soil Screening Guidance: Users Guide. EPA/540/R-96/018

17. United States Environmental Protection Agency (2002) Supplemental Guidance for Developing Soil Screening Levels for Superfund Sites. OSWER 9355.4-24. 